Original Research Paper

\title{
Pelatihan Pembuatan Preparat Kromosom Politen Drosophila Melanogaster Pada Guru-Guru Biologi Di Lombok Barat
}

\author{
I Gde Mertha ${ }^{1 *}$, Ahmad Raksun ${ }^{1}$, Syachruddin AR ${ }^{1}$, Syamsul Bahri ${ }^{1}$ \\ ${ }^{1}$ Program Studi Pendidikan Biologi, FKIP Universitas Mataram, Mataram Indonesia
}

DOI: https://doi.org/10.29303/jpmpi.v3i2.522

Sitasi:. Mertha. I. G., Raksun, A., Syachruddin, A. R. \& Bahri, S. (2020). Pelatihan Pembuatan Preparat Kromosom Politen Drosophila Melanogaster Pada Guru-Guru Biologi Di Lombok Barat. Jurnal Pengabdian Magister Pendidikan IPA, 3(2)

\author{
Article history \\ Received: 25 Oktober \\ Revised: 15 Nopember \\ Accepted: 29 Nopember \\ *Corresponding Author: \\ I Gde Mertha, \\ Program Studi Pendidikan \\ Biologi, Universitas Mataram, \\ Mataram, Indonesia. \\ Email: \\ igdemertha@yahoo.co.id
}

\begin{abstract}
Genetika sesungguhnya merupakan topik sains yang sangat menarik dan penting untuk diajarkan di sekolah karena berhubungan erat dengan penurunan sifat sehingga menjadi dasar pengembangan ilmu biologi dan ilmu lain yang tekait dengan biologi. Keterbatasan keterampilan guru dalam menyiapkan materi praktikum kromosom merupakan salah satu kendala dalam pembelajaran genetika, sehingga konsep genetika yang disampaikan di kelas belum terintegrasi dengan praktikumnya. Oleh sebab itu teknik pembuatan preparat kromosom dan pengamatannya perlu dikuasai guru-guru biologi. Kegiatan pengabdian ini telah dilaksanakan di SMA Negeri 1 Labuapi, Kabupaten Lombok Barat. Tujuan pengabdian ini adalah memberikan pendampingan praktikum teknik isolasi kelenjar saliva Drosophila melanogaster sebagai sumber kromosom dan pendampingan praktikum preparasi kelenjar tersebut untuk pengamatan kromosom politen. Metode yang digunakan pada kegiatan pengabdian ini adalah pelatihan dan unjuk kerja dalam bentuk pendampingan praktik yang dikombinasikan dengan ceramah, diskusi dan tanya jawab. Kegiatan praktik yang telah dilakukan, yaitu (1) Teknik isolasi kelenjar saliva larva instar III D.melanogaster, (2) Teknik preparasi kelenjar saliva untuk pengamatan kromosom politen, (3) Observasi morfologi kromosom politen dibawah mikroskop, (4) Observasi struktur detail kromosom politen (band, interband, dan puff) dibawah mikroskop, dan (5) Dokumentasi morfologi dan struktur detail kromosom politen dibawah mikroskop. Hasil pelatihan menunjukkan bahwa (1) Pengabdian pada masyarakat ini sangat bermanfaat bagi guru mitra karena dapat menambah wawasan dan keterampilan dalam pembuatan preparat kromosom politen D. melanogaster, pengamatan morfologi dan struktur detail kromosom politen, dan teknik dokumentasi kromosom dibawah mikroskop, (2) Respon yang tinggi dan ketekunan guru mitra dalam mengikuti pelatihan sangat mendukung keberhasilan praktik pembuatan prepaat squash kelenjar saliva untuk menghasilkan perangkat pembelajaran preparat kromosom politen, dan (3) Preparat kromosm politen yang dihasilakn guru mitra dalam pelatihan dapat digunakan sebagai bahan praktikum untuk meningkatkan pemahaman siswa dalam pembelajaran genetika di sekolah
\end{abstract}

Keywords: Preparat Kromosom, Politen. 


\section{Pendahuluan}

Genetika sesungguhnya merupakan topik sains yang sangat menarik dan penting untuk diajarkan di sekolah karena aplikasinya berhubungan erat dengan penurunan sifat dan menjadi dasar bagi pengembangan ilmu biologi maupun ilmu lain yang terkait dengan biologi (Roini, 2013). Menurut Th. Dobzhansky dalam Ayala dan Kinger (1984) bahwa "Nothing in biology is understandable except the light of genetics. Genetics is the core biological science". Namun dilain pihak, genetika juga merupakan topik yang relatif berat karena konsep-konsep genetika umumnya dianggap bersifat abstrak (Corebima, 2009). Materi genetika juga bersifat esoterik karena meliputi obyek-obyek yang bersifat mikroskopik dan proses-prosesnya di luar kehidupan sehari-hari siswa (Tsui dan Treagust, 2003 dalam Roini, 2013). Kondisi ini menyebabkan genetika merupakan materi yang dianggap sulit baik oleh guru maupun siswa.

Menurut Suryo (1995) bahwa anggapan semua topik genetika berdasarkan materi yang bersifat abstrak tidak selalu benar. Dengan adanya perkembangan teknologi mikroskop cahaya saat ini, materi genetik kromosom dapat dikenal dengan baik dan dapat divisualisasikan sehingga dapat sebagai bahan pembelajaran yang mudah diperoleh (Mertha et al., 2019; Mertha et al., 2019), begitu pula gambar komosom yang sangat rinci dengan visualisasi mikroskop elektron. Melalui praktik penyilangan hewan yang berbasis kromosom, siswa akan lebih cepat memahami konsep genetika Mendel (Fauzi dan Corebima, 2016). Begitu pula analisis karakter yang lebih mendetail secara molekuler dapat divisualisasikan dengan baik berupa pola larik-larik DNA. Hal ini menunjukkan bahwa pencapaian kompetensi pembelajaran konsep genetika akan mudah dipahami apabila memanfaatkan fasilitas dengan baik dan ada kemauan untuk melakukan kegiatan praktik.

Dalam pembelajaran genetika di tingkat SLTA, beberapa indikator pencapaian kompetensi yang ingin dicapai yaitu (1) menguraikan struktur dan fungsi gen, DNA, RNA, kromosom dan (2) menjelaskan mekanisme ekspresi gen dalam mensitesis protein (DNA-RNA-Protein). Untuk mendapatkan pemahaman yang baik pada kedua indikator diperlukan pengetahuan dasar tentang substansi genetik pada tingkat subsel dan molekuler yang tidak semua bersifat abstrak. Berdasarkan indikator ketercapaian tersebut, maka dalam upaya pencapaian kompetensi diperlukan pembelajaran yang tidak hanya berbasis konsep tetapi juga praktik laboratorium.

Namun berdasarkan fakta yang terjadi di lapangan, indikator pencapaian kompetensi tersebut belum tercapai sepenuhnya karena kebanyakan guru dan juga pengajar calon guru lebih sering menggunakan metode ceramah (Suratsih et al., 2009). Kondisi ini didukung hasil survey yang dilakukan terhadap guru-guru biologi di Kabupaten Lombok Barat sejak tahun 2015 menunjukan bahwa pembelajaran yang mereka terapkan belum banyak menggunakan multi metode, multi media, dan belum pernah dilakukan praktik laboratorium. Akibatnya, respon, inisiatif maupun interaksi antara guru dengan siswa dalam pembelajaran masih sangat rendah. Hal ini menyebabkan pembelajaran hanya berpusat pada guru dan siswa hanya memahami konsep bukan pelaku pembelajaran inovatif berbasis praktik.

Pada kelenjar saliva lalat buah (Drosophila melanogaster) ditemukan kromosom yang berukuran lebih besar dari ukuran kromosom normal, yang biasa disebut kromosom raksasa (polytene chromosom atau kromosom politen) (Suryo, 1986). Menurut Kimball (1998), kromosom raksasa ini memiliki ukuran seratus kali lebih besar daripada ukuran kromosom normal. Kromosom raksasa ini menunjukkan detail struktur yang lebih jelas dari kromosom normal. Bentuk kromosom raksasa pada lalat buah ini adalah linier atau batang. Kromosom raksasa terdiri dari dua daerah yaitu daerah pita yang gelap (band) dan pita yang terang (interband) yang terletak berselang-seling secara bergantian. Pada daerah pita yang gelap terdapat banyak DNA. Pada daerah ini, kromatin mengalami kondensasi atau pelipatan secara maksimal yang disebut sebagai heterokromatin yang berperan aktif pada saat terjadi pembelahan. Heterokromatin dengan lilitan padat yang mengalami kondensasi adalah gen yang tidak terekspresi (Kimball, 1998). Sedangkan pada interband atau pita terang tidak terjadi kondensasi. Pada pita terang ini terdapat eukromatin dengan lilitan renggang. Band yang terurai membentuk puff. Puff adalah gen aktif pada transkripsi RNA (Wolfe, 1993). Kromosom politen D. melanogaster yang sering digunakan untuk penyelidikan genetika mempunyai jumlah kromosom sedikit, yaitu 8 kromosom, terdiri atas 6 autosom dan 2 kromosom kelamin (Suryo, 1986). Preparasi atau pembuatan preparat kromosom ini 
lebih mudah dan murah dibandingkan dengan preparasi kromosom biasa (Darlington dan La Cour, 1960). Karena ukuran kromosom yang sangat besar, struktur yang lengkap (adanya kromosenter, kromonemata, band, interband, dan puff), dan preparasi yang murah dan mudah, maka kromosom D. melanogaster merupakan substansi genetik yang baik dalam memberikan gambaran DNA yang membentuk kromatin, visualisasi kromatin yang mengawali replikasi DNA dalam sintesis protein, dan gambaran detail struktur komosom.

Berdasarkan uraian di atas, visualisasi karakteristik kromosom politen akan sangat menunjang peningkatan indikator pencapaian kompetensi dalam pembelajaran genetika di sekolah. Pembuatan kromosom politen jauh lebih singkat dan sederhana dibandingkan dengan pembuatan kromosom biasa, dan dapat dikerjakan di sekolah. Namun kendala yang dihadapi guruguru mitra dalam praktikum pembuatan slide kromosom tersebut adalah mereka belum memahami cara isolasi kelenjar saliva dan preparasi kelenjar tersebut menjadi preparat kromosom politen, serta identifikasi kromosom dibawah mikroskop. Oleh sebab itu tujuan yang diharapkan dari kegiatan pengabdian ini adalah melakukan pendamping praktikum mikroteknik pembuatan preparat mikroskopis kromosom politen yang diambil dari kelenjar saliva larva lalat buah (D. melanogaster) dan melatih keterampilan observasi struktur detail kromosom tersebut di bawah mikroskop. Sedangkan manfaat yang diharapkan dari kegiatan pengabdian ini adalah peningkatan keterampilan dan keahlian guru-guru biologi di Kabupaten Lombok Barat dalam pembuatan preparat kromosm politen dan kemampuan identifikasi kromosom untuk meningkatkan kualitas pembelajaran.

\section{Metode}

Metode yang digunakan pada kegiatan pengabdian ini adalah pelatihan dan unjuk kerja dalam bentuk pendampingan praktek yang dikombinasikan dengan ceramah, diskusi dan tanya jawab. Kegiatan penyampaian materi pada pelatihan ini dilakukan secara klasikal, dimana semua peserta (guru-guru mitra) mengikuti materi yang disampaikan dengan cara ceramah, diskusi dan tanya jawab.

Setelah selesai kegiatan penyampaian materi, selanjutnya dilakukan unjuk kerja praktik.
Pada saat praktikum dilakukan pendampingan untuk memberikan bimbingan dan validasi pada kinerja praktik guru-guru mitra.

Kegiatan praktikum pembuatan preparat kromosom politen dilakukan pada jaringan kelenjar saliva lalat buah (D. melanogaster). Masing-masing peserta melakukan pengamatan preparat kromosom politen yang sudah selesai dikerjakan dibawah mikroskop dengan pendampingan dari tim pengabdian. Pengamatan dilakukan mulai dari perbesaran lemah sampai perbesaran kuat. Morfologi kromosom yang diamati adalah lengan kanan, lengan kiri, kromosenter, dan kemungkinan adanya paracentric inversion pada lengan kromosom. Untuk praktek pengamatan struktur detail kromosom dilakukan pencarian heterokromatin/band, eukromatin/interband, dan puff. Penentuan lengan kiri, lengan kanan, kromosenter, dan struktur detail kromosom mengacu pada gambar kromosom politen yang dipublikasikan Zhimulev dan Koryakov (2009).

\section{Hasil dan Pembahasan}

Program edukasi masyarakat dalam pengelolaan sampah di Desa Kumbang Kecamatan Masbagik Kabupaten Lombok Timur dalam rangka pemberdayaan masyarakat desa dilakukan secara terstruktur dan melibatkan masyarakat secara langsung seperti Karang Taruna, IPMAKU (Ikatan Pemuda Mahasiswa/i Kumbung), HPMD (Himpunan Pemuda Mahasiswa/I Bangket Daya), warga desa Kumbung secara umum. Program edukasi masyarakat tentang pengelolaan sampah ini merangkum tiga kegiatan yang berbeda dan bertujuan sekaligus untuk membantu penanganan masalah sampah yang terjadi di Desa Kumbang.

Pengabdian kepada masyarakat ini telah dilaksanakan dan telah berhasil memberikan bekal pemahaman yang benar pada guru mitra tentang pembuatan perangkat preparat pembelajaran dan keterampilan dalam observasi serta dokumentasi preparat tersebut untuk bahan pembelajaran genetika di sekolah. Dengan semangat dan ketekunan yang tinggi, guru mitra berhasil mengaplikasikan teknik histologi dan fotografi untuk menghasilkan bahan dan perangkat pembelajaran, yaitu (1) preparat (slide) kelenjar saliva D. melanogaster untuk pengamatan kromosom politen, (2) koleksi kelenjar saliva sebagai bahan 
praktikum pembuatan preparat kromosom politen, (3) foto morfologi kromosom politen termasuk tipe mutasinya, dan (4) foto struktur detail lengan kromosom. Disamping teknik pembuatan preparat, respon yang sangat baik terhadap pelaksanaan pelatihan ini ditunjukkan guru mitra dalam praktikum pengamatan morfologi kromosom politen dibawah mikroskop, keterampilan pengamatan struktur detail kromosom politen dibawah mikroskop, dan keterampilan identifikasi masing-masing kromosom politen.

Ada dua macam preparat kromosom politen yang dihasilkan dalam pelatihan, yaitu preparat yang menampilkan kromosom politen yang masih berada di dalam inti dan preparat squash yang menunjukkan kromosom politen dengan lengan yang terbuka (tidak banyak tumpang tindih). Pada preparat pertama membran inti masih membungkus kromosom politen (kromosom dikemas dalam inti), sedangkan pada preparat kedua membran inti telah pecah sehingga lengan-lengan kromosom politen dapat menyembul dan menyebar.

Praktik pembuatan preparat kromosom politen meningkatkan pengetahuan dan wawasan mitra dalam bidang mikroteknik. Hasil pemantauan selama pendampingan menunjukkan terjadi perubahan yang besar pada tingkat pemahaman materi kromosom dan keterampilan laboratorium guru mitra setelah diberikan pelatihan. Pengamatan saat pelatihan menunjukkan bahwa hampir semua peserta dapat membuat preparat kromosom politen dengan benar dan menjawab pertanyaan yang diberikan tim pengabdian. Keterampilan yang telah dikuasai guru mitra memberi manfaat yang besar dalam pembimbingan praktikum genetika di sekolah.

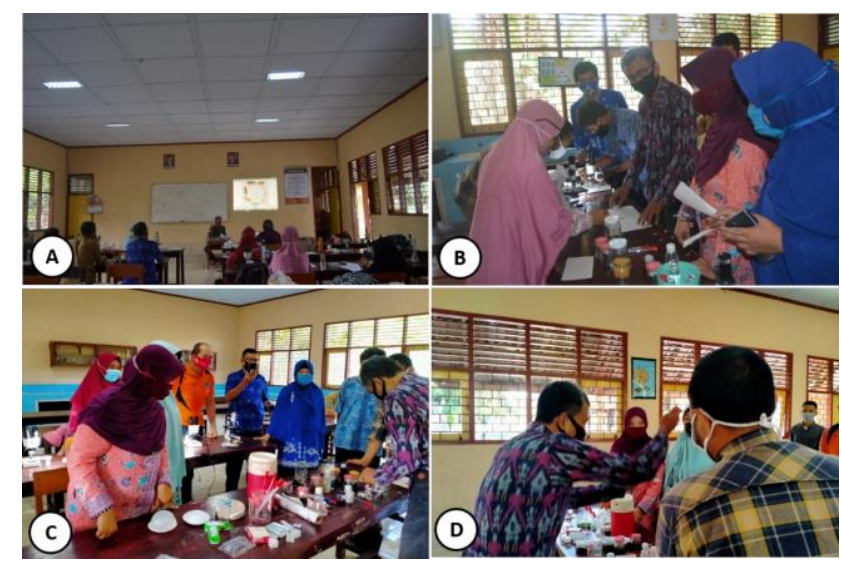

Gambar 1. Penyampaian materi pelatihan pembuatan preparat kromosom politen. A. Dosen menjelaskan kromosom politen Dosophila melanogaster dan prosedur pembuatan preparat squash. B. Penjelasan dosen tentang alat dan bahan pembuatan preparat squash kromosom politen. C. Dosen menunjukkan larva instrar III dalam botol biakan yang akan diisolasi kelenjar salivanya. D. Demonstrasi yang dilakukan dosen dalam pembuatan larutan garam fisiologis dan fiksatif.

Partisipasi aktif mitra dalam praktikum pembuatan preparat kromosom politen sangat tinggi. Partisipasi tersebut dibuktikan dengan antusias mereka dalam menyelesaikan tugastugas yang diberikan dalam menghasilkan produk pelatihan berupa preparat kromosom politen dan menunjukkan hasilnya pada tim pengabdian. Tugas yang dikerjakan guru mitra pada pelatihan ini adalah (1) praktik teknik isolasi kelenjar saliva (kelenjar ludah) larva instar III lalat buah D. melanogaster, (2) praktik teknik preparasi kelenjar saliva lalat buah untuk pengamatan kromosom politen, (3) praktik observasi morfologi kromosom politen (lengan kanan, lengan kiri, kromosenter) dibawah mikroskop, (4) praktik observasi struktur detail 


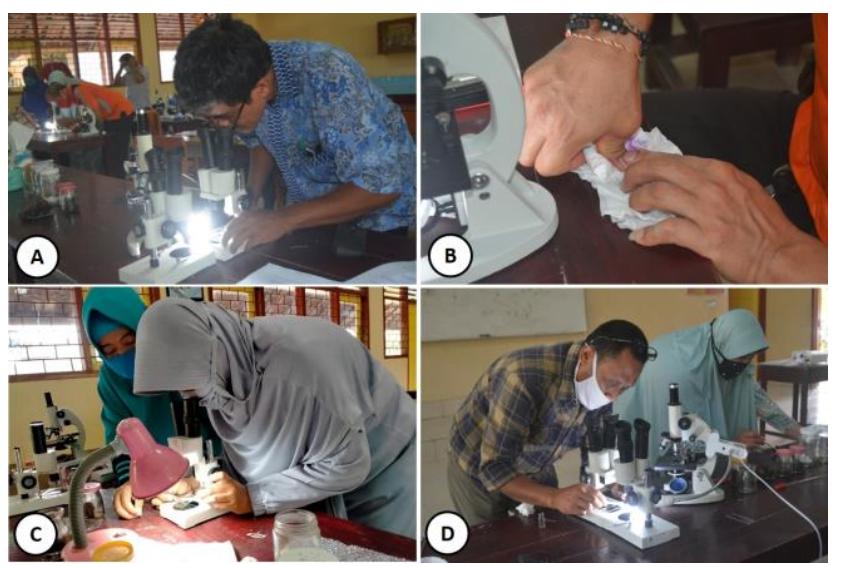

Gambar 2. Kegiatan pelatihan pembuatan preparat squash kelenjar saliva Drosophila melanogaster untuk pengamatan kromosom politen. A, C, D. Guru biologi sedang melakukan praktek isolasi kelenjar saliva Drosophila melanogaster dibawah mikroskop bedah. B. Proses squashing (pemencetan) dalam pembuatan preparat squash kelenjar saliva.

kromosom politen (heterokomatin/band, eukromatin/interband, dan puff) lalat buah dibawah mikroskop, dan (5) praktik dokumentasi (pengambilan gambar foto) morfologi dan struktur kromosom politen lalat buah dibawah mikroskop.

Dengan mengacu pada teknik preparasi squash kelenjar saliva yang telah disusun untuk kegiatan pelatihan, guru mitra melakukan unjuk kerja praktikum pembuatan preparat komosom politen D. melanogaster. Langkah pertama yang harus dilakukan dalam pembuatan preparat kromosom politen dalam pelatihan ini adalah menyiapkan kelenjar saliva. Isolasi kelenjar saliva dilakukan pada larva instar III lalat buah D. melanogaster. Keberhasilan pembuatan preparat kromosom politen banyak ditentukan pada keterampilan kedua proses tersebut.

Hasil pengamatan selama pelatihan menunjukkan bahwa proses isolasi kelenjar saliva harus dilakukan secara cermat oleh guru biologi karena tahapan ini membutuhkan keterampilan yang perlu banyak latihan. Pengambilan kelenjar saliva dilakukan dengan cara memisahkan bagian badan dan kepala larva dengan bantuan jarum pentul dalam larutan saline (garam fisiologis). Salah satu ujung jarum pentul menekan badan larva sedangkan ujung jarum yang lain menekan dan mendorong kepala larva sampai bagian kepala dan badan terpisah yang diikuti pemisahan kelenjar saliva dari badan larva. Dalam perjalanan pelatihan, jarum pentul untuk menekan bagian badan larva diganti dengan pinset yang ujungnya sangat runcing. Hal ini dilakukan karena guru kesulitan menahan badan larva dengan jarum pentul. Melalui latihan berulang-ulang semua guru biologi peserta pelatihan dapat melakukan isolasi kelenjar saliva dengan baik. Kelenjar saliva yang berhasil dikeluarkan dari tubuh larva harus dibersihkan dari jaringan lemak yang masih menempel. Hasil pengamatan menunjukkan bahwa seringkali kelenjar saliva putus atau hancur saat pemisahan jaringan lemak. Untuk mengatasi kendala tersebut maka pemisahan dilakukan pada saat kelenjar terendam larutan fiksatif (difiksasi) dalam alkohol absolut dan asam asetat glasial (1:1). Dengan cara ini jaringan lemak yang menempel pada kelenjar saliva dengan mudah dapat dipisahkan menggunakan kuas kecil.

Keterampilan melakukan squash pada kelenjar saliva yang telah diwarnai dengan carbolic fuchsin akan menentukan sebaran sel dan sebaran lengan kromosom politen. Untuk memberi petunjuk teknik squash yang baik, tim pengabdian melakukan demonstrasi squash dan melakukan pendampingan pada saat squash dilakukan peserta pelatihan. Sebelum dilakukan squash, kelenjar saliva yang telah diwarnai tersebut ditetesi lagi dengan pewarna (setelah pewarna awal dihilangkan), kemudian ditutup dengan gelas penutup. Gelas penutup diketuk-ketuk dengan ujung gagang kuas atau karet penghapus pensil agar sel-sel tersebar dan selanjutnya dilakukan squash. Kegagalan yang sering terjadi antara lain karena pada saat dilakukan squash gelas penutup bergeser. Pergeseran gelas penutup dapat mengakibatkan kromosom terlipat. Teknik pengetukan menggunakan ujung gagang kuas juga mempengauhi hasil preparat jika tidak dilakukan secara benar, pengetukan yang terlalu keras dapat mengakibatkan lengan 
kromosom putus. Dengan ketekukan yang tinggi dan rasa ingin tahu yang besar, guruguru biologi melatih keterampilan squash beulang-ulang pada kelenjar saliva. Berkat latihan dan pendampingan oleh tim pengabdian mereka berhasil membuat preparat kromosom politen yang bagus yang ditandai lengan kromosom yang tersebar. Kromosom politen dengan lengan yang tersebar dapat dibuat semi permanen dengan menyegel tepi gelas penutup dengan pengkilap kuku (kuteks) bening. Selanjutnya, melalui pendampingan oleh tim pengabdian peserta pelatihan dapat melakukan identifikasi

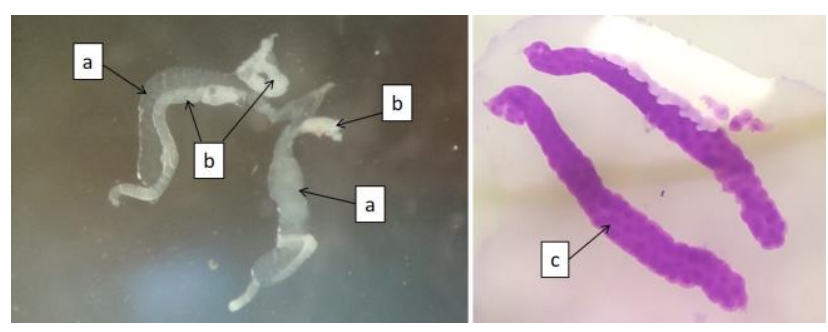

Gambar 3. Kelenjar saliva dibawah mikroskop bedah. Gambar kiri: kelenjar saliva dengan jaringan lemak yang masih menempel. Gambar kanan: kelenjar saliva yang diwarnai dengan carbolic fuchsin. $\mathrm{a}=$ kelenjar saliva; $\mathrm{b}$ $=$ jaringan lemak; $\mathrm{c}=$ inti sel-sel politen.

individu kromosom yang tergabung dalam kromosom politen D. melanogaster. Demikian pula penentuan panjang lengan kromosom dapat ditentukan dengan baik, kecuali beberapa kromosom politen yang lengannya masih tumpang tindih atau terlipat maka harus dilakukan secara lebih cermat.

Melalui pengamatan dibawah mikroskop terhadap preparat squash kromosom politen yang bagus (lengan tersebar), peserta pelatihan dapat mengamati morfologi kromosom politen dan struktur detail pada lengan. Morfologi kromosom yang dapat diamati antara lain lengan kiri dan lengan kanan kromosom nomor 2 (2L, 2R) dan kromosom nomor 3 (3L, 3R), kromosom $\mathrm{X}$, kromosenter, dan peristiwa paracentric inversion. Identifikasi bagianbagian kromosom tersebut dilakukan peserta pelatihan dengan mengacu pada gambar skematis kromosom politen D. melanogaster dalam publikasi Zhimulev dan Koryakov (2009). Adapun pertanyaan yang muncul dari peserta pelatihan pada pengamatan mofologi kromosom ini adalah "Mengapa kromosom nomor 4 sulit diamati pada kromosom politen D. menalogaster". Jawaban yang diberikan tim pengabdian adalah "Kromosom nomor 4 sangat kecil dan sulit dibedakan dari kromosenter". Struktur detail pada lengan kromosom yang penting untuk dimati adalah heterokromatin (band), eukromatin (interband), dan puff. Pengamatan struktur detail lengan kromosom politen dibawah mikoskop menambah pengalaman berharga guru mitra dalam membedakan DNA lilitan padat (band) dan DNA lilitan longgar (inteband), serta posisi gen-gen dalam status aktif yang sedang melakukan transkripsi RNA (puff). Adapun pertanyaan peserta pada pengamatan struktur kromosm diatas, yaitu "Mengapa bentuk puff menggembung". Jawaban yang diberikan tim pengabdian adalah "Penggembungan terjadi karena kromatin pada lengan kromosom politen mengalami relaksasi, lengan komosom sedikit terbuka. Menurut Zhimulev dan Koryakov (2009) bahwa penggembungan tersebut terjadi karena induksi ecdysone atau shock-panas".

Pengambilan foto kromosom politen dibawah mikroskop umumnya dilakukan pada mikroskop yang dilengkapi dengan kamera foto. Semua mikroskop yang digunakan dalam pelatihan ini merupakan mikroskop cahaya standar yang tidak memiliki kamera. Pengambilan foto dari mikroskop standar tesebut dapat dilakukan dengan menggunakan kamera digital SLR atau kamera handphone dengan cara mengarahkan lensa kamera tersebut pada lensa okuler mikroskop. Harap diperhatikan bahwa pada saat pengambilan foto, jarak fokus harus diatur. Jarak fokus sudah sesuai apabila telihat lingkaran lensa okuler pada handphone atau kamera SLR. Pemotretan dapat dilakukan pada tampilan demikian, namun kita harus melakukan editing karena gambar yang dihasilkan dalam lingkaran. Untuk itu perlu dilakukan pengaturan agar bidang pandang dalam 
mikroskop menjadi tampak penuh pada kamera. Apabila jarak fokus telah mantap, maka posisi kamera dapat dibuat permanen dengan pemasangan penyangga yang disesuaikan (tripod khusus).

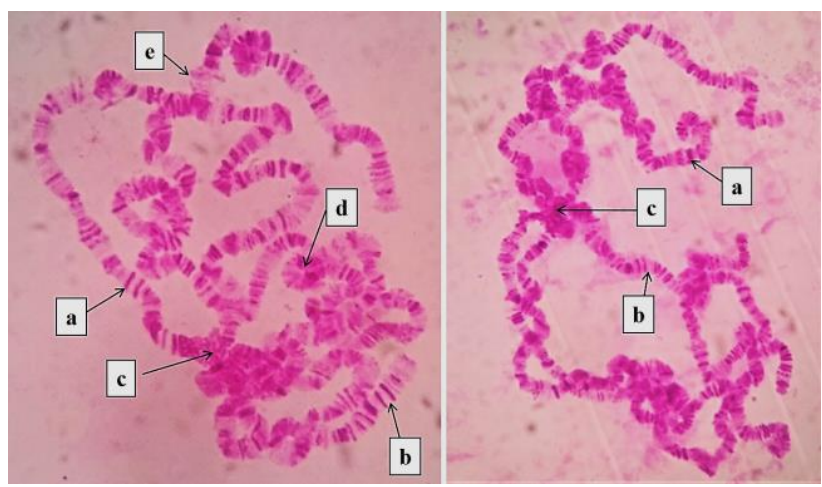

Gambar 4. Hasil praktek pemotretan kromosom politen Drosophila melanogaster dibawah mikroskop cahaya pada perbesaran 1000x oleh guru mitra. $\mathrm{a}=$ heterokromatin (band); $\mathrm{b}=$ eukromatin (interband), $\mathrm{c}=$ kromosenter; $\mathrm{d}=$ paracentric inversion; $\mathrm{e}=$ puff.

Hasil dokumentasi berupa foto-foto kromosom politen D. melanogaster yang diperoleh dalam pelatihan ini penting sebagai media pembelajaran yang sangat bermanfaat dalam memfasilitasi guru biologi untuk meningkatkan pemahaman siswa pada materi genetika. Visualisasi terjadinya mutasi, DNA yang tidak aktif (lilitan padat) dan DNA yang aktif (lilitan longgar), serta kondisi pairing (berpasangan) dapat dijelaskan dengan baik dengan pengamatan kromosom politen. Struktur detail pada lengan kromosom politen dapat juga menjadi bahan penting dalam pemetaan kromosom dalam penentuan jarak genetik.

\section{Kesimpulan}

Berdasarkan hasil pengabdian pada masyarakat yang telah dibahas diatas dapat disimpulkan bahwa: (1) Pengabdian ini sangat bermanfaat bagi guru mitra karena dapat menambah wawasan dan keterampilan dalam pembuatan preparat kromosom politen D. melanogaster, pengamatan morfologi dan struktur detail kromosom politen, dan teknik dokumentasi kromosom dibawah mikroskop; (2) Respon yang tinggi dan ketekunan guru mitra dalam mengikuti pelatihan sangat mendukung pelaksanaan praktik pembuatan prepaat squash kelenjar saliva dalam menghasilkan produk perangkat pembelajaran preparat kromosom politen; (3) Preparat kromosm politen yang dihasilakn guru mitra dalam pelatihan dapat digunakan sebagai bahan praktikum untuk meningkatkan pemahaman siswa dalam pembelajaran genetika di sekolah.

\section{Ucapan Terima Kasih}

Terima kasih kepada Universitas Mataram yang telah mendukung secara moral maupun material, dan pihak-pihak terkait yang senantiasa selalu memberikan dukungan dalam terlaksananya kegiatan pengabdian kepada masyarakat ini.

\section{Daftar Pustaka}

Ayala, F. J. \& Kinger, J. A. 1984. Modern of Genetics. The Benjamin/cummings Publishing Company, Inc. Menlo Prk California.

Corebima, D. 2009. Pengalaman Berupaya menjadi Guru Profesional. Pidato Pengukuhan Guru Besar dalam Bidang Genetika pada Fakultas MIPA Universitas Negeri Malang, Malang, 30 Juli.

Darlington, C.D. dan L. F. La Cour, 1960. The Handling of Chromosomes. George Allen \& Unwin Ltd. London.

Fauzi, A. dan A. D. Corebima. 2016. Pemanfaatan Drosophila melanogaster sebagai organisme model dalam mengungkap berbagai fenomena rasio Mendel. Prosiding Seminar Nasional Biologi 2016, ISBN: 9786020951 119.

Kimball, J.W. 1998. Biologi. Erlangga. Jakarta.

Mertha, I.G., A. Al Idrus, S. Bahri, P. Sedijani, dan D.A.C. Rasmi. 2019. Pelatihan teknik pembuatan preparat squash ujung akar untuk pengamatan kromosom pada guru-guru biologi di Kota Mataram. Jurnal Pendidikan dan Pengabdian Masyarakat, November 2019, Vol. 2, No. 4: $454-459$. 
Mertha, I.G., S. Bahri, L. Zulkifli, A. Ramdani, dan N. Lestari. 2019. Pelatihan pembuatan preparat kromosom dan peyusunan karyotipe di Fakultas Mipa program studi Biologi Universitas Islam Al-Azhar Mataram. Jurnal Pengabdian Magister Pendidikan IPA 2019, (2) 1: 75-78.

Roini, C. 2013. Organisasi konsep genetika pada buku biologi SMA kelas XII. Jurnal EduBio Tropika, Volume 1, Nomor 1, Oktober 2013: 1-60

Suratsih, V. Henuhili, T. Rahayu, dan M. L. Hidayat. 2009. Pengembangan modul pembelajaran genetika berbasis fenomena lokal. Cakrawala Pendidikan, Juni 2009, Th. XXVIII, No. 2: 165 - 176.

Suryo, 1986. Genetika Manusia. Gadjah Mada University Press. Yogyakarta.

Suryo, 1995. Sitogenetika. Gajah Mada University Press. Yogyakarta.

Wolfe, S. L. 1993. Molecular and cellular biology. Wadsworth, Inc. California.

Zhimulev, I.F. dan D.E. Koryakov. 2009. Polytene Chromosomes. Encyclopedia of Life Sciences. John Wiley \& Sons, Ltd. Chichester. 